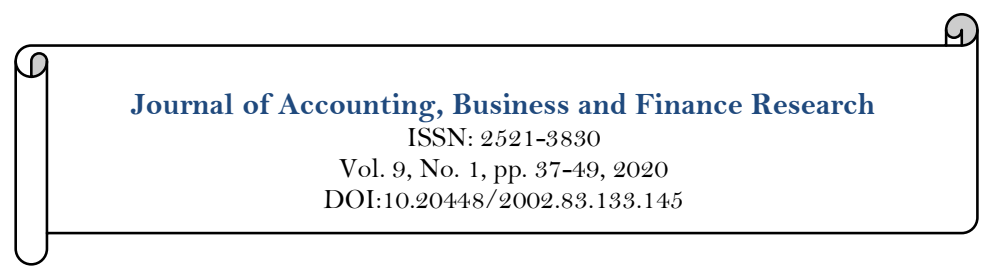

\title{
Impact of Management Accounting on Decision Making: A Zimbabwean Perspective
}

\author{
Nyamwanza L. ${ }^{1}$ \\ Mvundla $\mathbf{N}^{2}$ \\ Madzivire E. ${ }^{\text {s }}$
}

'Midlands State University, Gweru, Zimbabwe.

Email:nyamwanzal@staff.msu.ac.zw

${ }^{2} 64.6$ Crete Road, Waterfalls, Harare, Zimbabwe.

Email:nyashamvundla@gmail.com

${ }^{s}$ International Training College, Lingua, Windhoek, Namibia.

Email:emadzivire@gmail.com

\section{Abstract}

The aim of the study was to assess the impact of management accounting practices on the decision-making process of the entity operating within the manufacturing sector using a case of Capadvise Foods and Logistics (Pvt) Ltd. The research study was based on the period from 2014 to 2017 which was majorly characterised by huge amounts of losses. Capadvise Foods experienced huge amounts of losses in spite of the existence of management accounting practices. This encouraged the researchers to seek out an in-depth insight on the impact of management accounting on decision making in light of such losses which were continually experienced. The researchers made use of questionnaires and interviews to collect qualitative and quantitative data about the opinions and attitudes of employees and management at Capadvise Foods regarding management accounting tools. The researchers found that management accounting tools contributed positively to the organisational decision making through provision, interpretation and analysis of data, enhancement in communication, relevant cost analysis and creation of budgets and forecasting. However, the researchers found that management accounting practices were compromised by technological advancement, organisational strategy, organisational factors and intensity of market competition. After analysing the results attained the researchers recommended for Capadvise Foods which include enrolling qualified management accounting staff, decision makers are allowed to make use of internal reports generated by management accountants and adoption of management accounting practices in order to allow proper and accurate decision making to take place.
Keywords:

Management accounting

Decision making.

Licensed:

This work is licensed under a

Creative Commons Attribution 4.0

License.

Publisher:

Scientific Publishing Institute

Received: 19 February 2020

Revised: 27 March 2020

Accepted: 3 April 2020

Published: 21 April 2020

Funding: This study received no specific financial support.

Competing Interests: The authors declare that they have no competing interests.

\section{Introduction}

Research has established the relationship between management accounting and decision making. Burns (2013); Darly (2017); Emma (2016); Garteinstein (2018) and Reddy (2016) said that management accounting improves decision making because it provides information relating to the present financial condition of the company. Eldenburg (2017) and Piersiala (2017) further supported that management accounting enhances decision making in health sector because it results in reliable information on costs incurred which is a necessary condition for both managers and decision makers. On the contrary Anderson and Decker (2018); Dierynck and Labro (2018); Ha (2017) and Piersiala (2017) said that management accounting leads to poor 
decision making in the health sector since settlement of health services requires the multiplicity of resources, collection of numerous necessary costs and statistical data which is a complex process within health services. Nian and Nair (2017) and Sunarni (2017) disagreed saying management accounting has no effect on decision making within construction entities since it is undermined by technological advancement, inexperience of accounting staff and intensity of market competition. This research looked at effects of management accounting in the organisational decision making within the manufacturing segment.

Capadvise Foods and Logistics (Pvt) Ltd, is a manufacturing organisation facing inadequate application of management accounting techniques in the organisational planning, control and in the decision-making process. The outcome further revealed that achieving exact, precise and trustworthy information on profit and financial performance was now a confront that the management was facing. Burns (2013); Poll (2014) and Drury (2013) said that a valid classification of expenditure pattern can be presented by the organisation managing massive amounts of erroneous data through the exercise of management accounting. Table 1 below reveal the revenue, operating costs and profit and losses of the firm.

Table-1. Extract of financial statements from 2014-2017.

\begin{tabular}{l|c|c|c|c}
\hline Description & $\mathbf{2 0 1 4}$ & $\mathbf{2 0 1 5}$ & $\mathbf{2 0 1 6}$ & $\mathbf{2 0 1 7}$ \\
\hline & $(\$ 000)$ & $(\$ 000)$ & $(\$ 000)$ & $(\$ 000)$ \\
\hline Revenue & 105 & 100 & 95 & 87 \\
\hline Operating Costs & 109 & 115 & 125 & 130 \\
\hline
\end{tabular}

Table 1 shows a trend of revenue, operational costs and net losses from the financial statements extract. The sales dropped from $\$ 105000$ to $\$ 100000$ that is a $47 \%$ decrease in sales from 2014 to 2015 period. This was due to a shift in management accounting department. This is supported by Army (2013); Hogan (2014) and McConnache (2017) saying that senior management shifts in organisations impact sales results for months; management should be clear and honest about changes of the sales strategies, reviewing up the performance of the previous sales using historical data to extrapolate sales quarter to quarter to ensure smooth sailing.

The sales continued to decrease from $\$ 100000$ to $\$ 95000$ by a $40 \%$ drop off during 2015 to 2016 financial period. This was due to inaccurate sales forecast by management. This was in support with Hogan (2014) and McConnache (2017) saying that without the use of statistics to analyse sales from month to month it is as good as just guessing. Use of data analytics will significantly improve accuracy and reliability of the forecasts which will in turn assist in avoiding falling short in achieving goals of the next financial period.

The firm's operating costs for the company rose from $\$ 109,000$ to $\$ 115,000$ by $52 \%$ that is from 2014 to 2015. The increase was because management accounting staff would formulate budgeted costs in allocation of costs which were lesser than actual costs not making an allowance for the future costs for hiring party time personnel and costs for machine breakdown. Annemans (2018); Duff and Evan (2014); Garteinstein (2018) and Tiwari (2015) stated that directed management of each department must implement cost analysis to drive productivity improvements in their departments as they are considered in management decisions and to track success of their departments. Therefore, management should implement savings to execute for unknown and unfunded needs without asking for a budget increase so as to accomplish a challenging program within a budget.

According to finance manager of Capadvise Foods the average salary per employee was $\$ 650$ from 2016 to 2017 as the number of employees were 45. The company employed 15 additional employees resulting in $\$ 29,250$ increment of direct labour costs forming a bigger sum of $\$ 125$, 000 increase of operating costs. This increased operating profits from $80 \%$ to $89 \%$. This was due to an increase in the direct labour so as to increase productivity. This was in line with Aurora (2013) and Chang (2013) said that direct labour cost is an ongoing cost of a business which cannot be attributed to a specific cost object.

Table 1 above also showed that the company incurred losses from $\$ 4,000$ to $\$ 15,000$ that is a decrease from $60 \%$ to $50 \%$ in the course of 2015 to 2016 financial period. This was caused by financial factor. Grant and Yeo (2017) asserted that financial factors significantly influence sales growth and financial performance. According to Capadvise Financial Report (2017) in June 2015 the firm took out a loan from Stanbic Bank worth $\$ 80,000$ with a $45 \%$ interest rate to finance an addition to its manufacturing plant being paid within three years. Financial Report (2017) the interest on this loan was deducted from operating profit since high rate was charged this affected the profit of the firm. According to Annual General Meeting Minutes (2017) showed that this phenomenon largely pointed out that there was inadequate application of management accounting practices in the organisational decision making by management since they acquired loan, they could not manage to refinance quarterly making interest costs higher than profit.

Losses continued to override net profit of the firm this can be seen on Table 1 above as they escalate from $\$ 30,000$ to $\$ 43,000$ with a sharp decrease of $50 \%$ to $30 \%$ from 2016 to 2017 . This was as a result of poor organisational and financial control of funds in the finance and accounting department with disorganised 
management and very little or no financial control over firm's funds. Lien (2018) suggests that a firm should consider a focused management with strict financial control and a capable disciplined management accounting department which makes it easier to slip through the cracks on how to allocate funds effectively during the decision-making process. The research therefore focused on analysing the impact of management accounting on the decision-making process of Capadvise Foods that is in the manufacturing sector.

\section{Literature Review}

\subsection{Challenges in Implementing Management Accounting Techniques for Improving Decision Making}

Nian and Nair (2017) carried out a case study in Malaysia in analysing the challenges faced by manufacturing industries and the findings concluded that manufacturing industries have been facing many challenges in implementing management accounting techniques and these include lack of support from the top management, and qualified accounting staff. Sunarni (2013) furthermore goes on to say inadequate information and changes in business environment are challenges being faced by many organisations in implementing management accounting techniques.

\subsection{Insufficient Support from Top Management}

Tsai (2017) avers that one of the limitations causing the implementation of management accounting techniques in an organization is insufficient support from the top management. Tsai (2017) carried on to say top executives are not usually not concerned to reveal if the rightful management accounting techniques have been successfully implemented to enhance good decision-making process of an organization. Meiryuani (2014) suggests that top management have a tendency to be unaware concerning the exterior factors that hinder the utilisation of management accounting techniques that enhance decision making. Nian and Nair (2017) and Sunarni. (2013) went on to say that external factors include technological advancement, rapid changes in business environment and political stability are the most factors that management cannot take into consideration in implementing management accounting practices. Tsai (2017) said in line with this, top management tend to ignore these factors which are their responsibility; to examine these factors to make management accounting techniques effective and to enhance decision making of an organization. Sharet (2015) agreed that top management plays an essential role in generating innovative management accounting techniques by providing appropriate management accounting practices and make decisions that enhance creation and execution of knowledge successfully.

Nian and Nair (2017) argued that it is not the insufficient support from the top management that hinders the implementation of management accounting techniques in the overall decision making of the firm. Nian and Nair (2017) carried on to say that it is the lack of qualification and inexperience of the accounting staff that hinders the implementation of the management accounting techniques to enhance decision making. Nian and Nair (2017); Sanni and Hashim (2013) researchers furthermore conceded that non-qualified and inexperienced accounting staff tends to implement irrelevant management accounting techniques, making mistakes and poor decisions hence at times this is pervasive to the management accounting techniques objectives which will enhance poor decisions to be implemented in the future. Sunarni (2013) also supported the concept that top management is not responsible for implementing management accounting techniques it is the lack of communication between the accounting department and the other departments. Nian and Nair (2017) carried on saying, hence management accounting techniques is not coordinated effectively within the organization to enhance the decision making of the organization. The research sought to establish the sound effects of the involvement of Capadvise Foods' top management in improving decision making through the implementation of management accounting techniques.

\subsection{Inadequate Information}

Al-Sayyed (2015); Ankrah, Mensah, and Ofori-Atta (2015); Anna (2017) and Srivastava (2016) believe that being in the possession of inadequate information greatly affects the implementation of management accounting techniques in enhancing decision making of the company. Srivastava (2016) stated that inadequate and inappropriate use of management accounting information can detriment the fair view of management in decision making. Lognathan and Srivastava (2016) suggested that use of inadequate management accounting information is one of the most factors that pervade the organisational failure towards the management decision making process in accomplishing predetermined goals and objectives. Butterfield (2016) and Metcalf (2018) suggested that inadequate information may be as a result of carelessness, misinterpretation of data or unqualified accounting staff which will lead to making inappropriate management accounting techniques ensuing to bad decision making.

However, Muhsinzoda (2015); Phuong (2017) and Shanker (2017) agreed that inadequate information in implementing management accounting techniques is mainly aligned by the absence of information systems which will enhance decision making of an organisation. Muhsinzoda (2015) furthermore, supported this view by stating that information systems allow proficient operation of the organisation and they also provide sufficient and vast information to management. The researchers concluded that applying such information systems play a significant position in helping the organisation to position better value on information systems 
towards implementing suitable management accounting techniques in the organisation. According to the Financial Report (2016) Capadvise Foods has been failing to acquire all information essential for the organisation to conduct suitable management accounting practices for its decision-making process. Therefore, the research sought to establish the implication of inadequate information on Capadvise Foods' decision making.

\subsection{Rapid Changes in Business Environment}

Sulamain (2016) assert that rapid changes in business environment is another challenge faced by the organisation in implementing management accounting techniques in enhancing decision making of an organization. Sunarni (2013) furthermore, said that rapid changes in business environment often leads to changes in how organizations implement their management accounting techniques which will also damage management decision. Kloviene (2013) stated that rapid changes in business environment have an impact on the designing of management accounting techniques which will impact decision making process since management will often have limited skills on the design of the management accounting techniques. This is supported by Krishnan (2015) and Jovanovic (2015) suggested that changes in business environment has imposed new management accounting techniques and impositions of new regulations to be made which has completed the management decision making process to be challenging. Otley (2016); Sulamain (2016) and Krishnan (2015) agreed that rapid change in business environment has affected the implementation of management accounting information in a positive manner since it provides appropriate information to managers in order to meet the needs of decision making.

However, Talhat (2014) argued that a rapid change in business environment has no effect on the management accounting practices that enhance decision making of an organization. Talhat (2014) suggests that the emergence of the latest information technology and manufacturing technologies contributed much more to the challenge in implementing management accounting techniques in decision making. Furthermore, Talhat (2014) states that the trends in the economic environment also contributed to the transit of management accounting techniques that foster decision making. Nian and Nair (2017) the researchers concluded that rapid changes in business environment had no impact on implementation of management accounting techniques. The scholars brought the idea of the intensity of market competition that it had a major negative impact on the implementation of management accounting techniques that enhance decision making of an organization. The research sought to establish the effects of rapid changes in business environment on Capadvise Foods when implementing management accounting techniques to enhance decision making.

\subsection{Inexperience of Accounting Staff on Management Accounting Techniques}

Nian and Nair (2017) agreed that the inexperience of the accounting staff has an impact on the implementation and design of the management accounting techniques that enhance the sustainability in the organizational decision-making process. Nian and Nair (2017) carried on to say that insufficient information on management accounting techniques may serve a vital feature in the application of modern and existing management accounting practices which enhance decision making. Vitez (2018) and Cima (2018) and Chigara, Moyo, and Mudzengerere (2013) assert that continuous assessment and professional enlargement of employees through update learning, studies and seminars can overcome the challenge of lack of knowledge as a result, management accounting techniques can be useful to improve decision making in an organization. Nian and Nair (2017) agreed with the above notion saying that most of the accounting staff do not appreciate management accounting techniques hence they are not informed about the advantages of management accounting techniques that enhance decision making process of an organization.

Maiga (2013); Nian and Nair (2017) and Sunarni (2013) they alluded that management accounting techniques are useful and valid when implementing rapid information technology and several accounting staff are not well versed with the transit in information technology hence unawareness remain as a main problem in implementing appropriate management accounting techniques to achieve good decision making However, AlSayyed (2015) proposed that inexperience of the accounting staff in implementing management accounting techniques is not the main problem, it is the organization that does not increase the awareness concerning the formulation and technical knowhow in implementing appropriate management accounting techniques to enhance decision making process. Nian and Nair (2017) and Sunarni (2013) also believed that management accounting is a broad subject which requires a lot of concepts and comprising crucial aspects hence that should not be misinterpreted as management accounting techniques serve as a practice to foster decision making capabilities of an organization. Therefore, the research sought to establish the inexperience of accounting staff on management accounting practices to enrich comprehensive decision making. 
2.6. To Identify the Factors that Affect the Implementation of Management Accounting Techniques in Enhancing Decision Making

2.6.1. Technological Advancement

Amiri (2014); Nian and Nair (2017); Ratnatunga (2015) and Sunarni (2013) and they all agreed that advanced technology has a positive significant influence on the management accounting techniques in enhancing decision making of the organization. Amiri (2014) suggested that with technological advancement it improves the intra organizational roles which enable the management to identify the management techniques best suited within their department so as to enhance appropriate decision making. Klovienè and Gimzauskiene (2015) gave an illustration that information technology has changed the way in which management formulate the management accounting systems and techniques enabling analysis, interpretation and assessment of decision making. Nian and Nair (2017) conceded on to say that advanced production technology had a bigger impact on larger firms than in small medium enterprises. Nian and Nair (2017) concluded that advanced production machinery supported larger firms in their production activities. Nian and Nair (2017) carried out a research study and scholars concluded that technological constraints from the production process may affect the on designing new management accounting practices which will foster decision making capabilities within an organization. Furthermore, Klovienè and Gimzauskiene (2015) mentioned that information technology has caused a change in the issues of budgeting and reporting which are among the managerial accounting applications and enable the exercise of modern management accounting practices enhancing good decision making.

However, Ponnusamy (2017) suggests that technological advancement has a negative impact on the management accounting techniques in enhancing decision making. Ponnusamy (2017) furthermore alluded that with technological advancement all management accounting software need data to be entered physically that is if required information is not inspected for correctness, truthfulness and fullness information generated by accounting software will lead to misconception which foster management to design immaterial management accounting techniques enhancing incorrect decisions to be prepared. Sunarni (2017) suggests that technological advancement is unforeseen factor that affect management accounting techniques to enhance decision making. Sunarni (2017) carried on to say that organizational size and market competition were the main factors affecting management accounting techniques in decision making of an organisation. Therefore, this research sought to establish that technological advancement has influenced the management accounting techniques of Capadvise Foods.

\subsection{The Intensity of Market Competition and Economic Environment}

According to Benelifa (2017); Krishnan (2015); Siska (2016) and Yang, Lu, Tang, and Pei (2015) believe that growing markets and competition had a significant impact on the management accounting practices in enhancing decision making. Krishnan (2015) furthermore stated that growing of international markets and different cultural environment has enabled the management needing to reconsider its existing management accounting techniques and strategies in order to meet the competitive market and environment. Krishnan (2015) concluded that this will affect the implementation of innovative management accounting practices for the management to make sound decision making due to the intensity of market completion. Ahmad (2015) carried out a research case study in South Africa and the researcher concluded that the intensity of market competition and volatility of the environment contributed to the management accounting and control techniques change processes thereby affecting the decision making of the organization.

However, Ahmed (2014) argued that as time goes on an increase in market competition allows management to advance their management accounting techniques as it permits the organization to compete with other organisations within the same industry efficiently allowing the organization to formulate best decisions. Furthermore, Ahmed (2015) continued on to say with the intensity of market competition management gain facts, information and experience concerning new management accounting systems to compete within the business environment. Leite (2015) they examined the effect of market competition on management accounting techniques. Leite (2015) scholars concluded that intensity of market competition enabled the management to adopt management accounting practices assisting the management to verify how funds and resources have been utilised in each production process. Nian and Nair (2017) carried out a research study to examine the impact of market competition on management accounting techniques in manufacturing industries. Nian and Nair (2017) said that the results revealed that there was a significant connection between intensity of market competition and management accounting techniques as the economic environment feature affected the nature of management accounting systems to enhance decision making in Malaysia manufacturing companies. The research sought to establish the intensity of market competition and economic environment has affected management accounting techniques in decision making of Capadvise Foods.

\subsection{Organisational Factors}

Ahmed (2015); Nian and Nair (2017); Siska (2016) and Sunarni (2013) they all believed that organizational factors had a significant influence on the management accounting techniques to enhance decision making. Ahmed (2015) carried out a research study and the results revealed that the organizational size had a 
significant impact on management accounting practices in business decision making because larger firms had greater resources to facilitate management accounting practices as compared to small medium enterprises. In a research by Anertey and Mbuwani (2014) scholars carried out a research case study in examining management accounting techniques in Ghana telecommunication firms and the results were found that the nature and organizational size depends on the usage and reasons on the adaptation of the management accounting techniques that aid in decision making process of an organization. Benelifa (2017) suggested that the organisational size explains and justifies the use of management accounting techniques, the smaller the company is the lower sophisticated management accounting practices are adopted which makes it easier for the management to improve decision-making process. A study by Sunarni (2013) analysed the organizational size and management accounting techniques in manufacturing firms and the outcome revealed that only a minority of the manufacturing firms adopted the management accounting techniques because modern management accounting techniques were sophisticated to use in the manufacturing firms. Furthermore, Ismail and Al-Eqab (2013) concluded that majority of manufacturing firms adopted traditional management accounting techniques as they were simple and convenient to use.

Augustine and Haryanto (2013) suggested that organizational size is not the only factor that affects the adaptation of management accounting techniques in enhancing decision making of organization. Augustine and Haryanto (2013) carried on to say organizational culture also affect the management accounting practices since management will be restricted to usage of management accounting practices in pleasing to the eye in decision making of an organization. Ahmed (2015) and Benelifa (2017) also suggested that the type of business association that local companies face foreign affects the choice of management accounting practices. Benelifa (2017) conceded on to say companies controlled by other foreign companies adopt modern sophisticated management accounting techniques hence management will not have technical knowhow of the management accounting techniques hence devastating a good decision making. The research therefore sought to establish organisational factors have affected the enactment of Capadvise Foods management accounting techniques in enhancing decision making.

\subsection{Organisational Strategies}

Benelifa (2017); Mwali (2015); McLellan (2013) and Siska (2016) suggested that management accounting generally takes the organisational strategies as given and then examines the association between strategic choices and organisational management accounting systems and designs. Siska (2016) also goes on by examining the effect of organisational strategies on management accounting techniques and the results concluded that management accounting techniques are positively associated with adopting an appropriate business strategy, planned strategy formulation and accountant's strategic decision-making contribution. Farouk and McLellan (2013) scholars suggested that management accounting does not differ from one industry to another but rather from one strategy to another. The researchers concluded that the type of strategy must be supported with specific management accounting techniques that has an impact on the decision making of the firm. Amara and Benelifa (2017) suggested that an appropriate management accounting technique should support strategic priorities in order to improve decision making. Oboh (2017) and Khan, Rizwan, Islam, and Aabdeen (2015) reiterated that a strategy an organisation adopts in management accounting practices constitutes the logic underlying its interactions with its decision making.

However, Maziriri (2017); Pavalots (2015); Oyerogba (2015) and Wall (2014) believed that organisations that do not make use of information systems aligned with their strategic objectives are less likely to make logic decisions than organisations that aligned their information technology and strategy. Tan (2013) believed that in order to enhance decision making, use of management accounting techniques organisational strategy should be changed by employing advanced information technology. Oboh (2017) said that an organisation should transform its strategy so as to accommodate room for change in advanced management accounting techniques and decision-making process. Therefore, the research sought to establish organisational strategies as one of the factors that have influenced Capadvise foods management accounting techniques in enhancing decision making.

\subsection{To Determine the Impact of Management Accounting in Decision Making \\ 2.10.1. Provision, Interpretation and Analysis of Data}

Chanbari (2015); Michael (2016) and Muthyala (2017) all agreed through the analysis of management accounting techniques, management accounting serves to support management in analysing the alternative courses of action open to decision making. Butterfield (2016) and Rongala (2015) also supported this view by saying that using management accounting techniques data presented in a comparative manner makes it easier and effective for decision making. Russell (2014) and William (2013) carried on to say that with management accounting tools management design systems with control to accumulate data comparison and initiating the best practices that directs to provide fact-based information making sound decisions. Huthcerson (2018); Martin (2017) and Neislen (2017) the researchers suggested that management accounting practices in an organization show where, how and when the funds have been spent by evaluating the performance and 
showing the implication of choosing one plan instead of another hence making those valuable tools for decision making purpose.

However, Parikh (2013) and Reddy (2016) suggested that management accounting practices do not follow the accounting practices principles hence there will be no proper presentation, evaluation and analysis of data since it is based on the evaluation of management accountancy. Parikh (2013) also supported this by saying that this disturbs the decision making in an organization since management accounting techniques do not follow the General Accepted Accounting Principles. Reddy (2016) and Muthyala (2016) suggested management accounting only provides data but there is no provision for decision that must be taken which will enable the management to make biased interpretation, prejudiced and biased knowledge of data making it impossible for the organization to come out with an accurate decision. The research therefore sought to establish how the provision, interpretation and analysis of data is important for Capadvise Foods when making decisions through utilisation of management accounting techniques.

\subsection{Relevant Cost Analysis}

Cima (2017); Freedman (2018); McGrwa (2013) and Woodruff (2018) all agreed that management accounting techniques are essential for decision making through relevant cost analysis by providing cost transparency to the organisation. Ruliana (2015) goes on supporting the idea, by saying in the final stage of decision making process management will have an access of information about relevant costs since management will need the information for pricing decisions, how efficient they can utilize their resources and the evaluation of the product line thus enhancing good decision making. Novak (2017); Reistein (2017) and Simon (2014) suggested that making use of the management accounting practices enables the management to understand the cost behaviour in a company hence the management is able to make right decision towards the production costs. Cima (2017) was in line with this view saying that all relevant costs will be determined by reviewing how they will directly or indirectly affect the outcome of decision making.

However, Parikh (2013) stated that for one to use management accounting techniques in relevant cost analysis there is need for a broad scope, skills and knowledge to look into matters of management accounting of the organization. Reddy (2016) went on to say that lack of these skills can hamper the overall decisionmaking process due to the inefficiencies of the management. Reddy (2016) asserts that management accounting practices only focus on the area of costs and this affects the outcome of decision making since management will be only focused on how they can handle their costs without looking into other areas that affect decision making. Therefore, this may cause deficiency in the decision-making process. Matters (2018) believe that the accuracy and validity of management accounting techniques is based on relevant cost analysis records. The researcher concluded that the decision making of an organization is reliant on accuracy of the cost records hence inaccuracies will hint inappropriate decisions to be made in an organization. The research therefore sought to establish how effective is relevant cost analysis to Capadvise foods through the enactment of management accounting practices in an organisation to boost decision making.

\subsection{Creation of Budgets and Forecasting}

Diana (2013); Francis (2015); Johnston (2018); Lotich (2015) and Ray (2018) the researchers all agreed that with the utilization of management accounting techniques budgets can be used in determining the available funds and all the resources that are currently being used which amplify the decision making within a firm. Francis (2015) carried on to say management are able to formulate budgets for future forecasting thereby management accounting act as a technique for paving a passage for which management have to follow. Rongala (2015) asserts that forecasting generally involves using management accounting practices from the precedent to make rightful decisions concerning the point of view in future. Breuer (2013) alluded that through the exercise of management accounting techniques budgets and forecasting enable the management to be diligent as time moves on how they can execute business errors thus enabling decision making to be easier. Huthcerson (2018) concluded that budgets are important as they form an integral part of management accounting techniques.

However, Lotich (2015); Markovic (2015) and Johnston (2018) suggested that for management accounting techniques to be effective in forecasting, management accounting information needs to be more dependable and display value in terms of information supplied in driving firms' decision making. Sethy (2017) supported this by saying that budgets and forecasts are usually communicated by top management without the presence of the middle and lower management which will affect the objectivity of the decisions since the decisions of budgets and forecasts will be done only by top management which might cause the top management to make prejudiced and biased decisions. Bhutto (2015); Reddy (2016) and Singh (2017) carried on to say since management accounting techniques enable creation of budgets and forecasts therefore management must have knowledge and understanding of various fields in the organisation. Reddy (2016) believes that with limited knowledge of various fields in the organisation, taking into consideration insufficient knowledge about quantitative techniques, management will persist to make intuitive decisions. The research sought to establish how management accounting techniques is effective for the creation of budgets and forecasting for Capadvise Foods in enriching decision making. 


\section{Methodology}

The researchers used mixed research methods in this research of Capadvise Foods to analyse the impact of management accounting in the organisational decision making within the manufacturing sector. Quantitative design was undertaken in order to ascertain the sound management accounting practices, the effectiveness of management accounting and establish best management accounting practices. The researchers used descriptive statistics to assess the qualitative factors thus provision, interpretation and analysis of data, relevant cost analysis, creation of budgets and forecasts and enhancement in communication. This approach helped the researcher to explore the effectiveness of management accounting in decision making. Quantitative approach was utilised since it pointed out quantitative factors provision, interpretation of data, relevant cost analysis, creation of budgets and forecast and enhancement in communication complimenting management accounting on its impact in decision making, Sunarni (2013). Furthermore, it gave an insight on quantitative factors such as balanced scorecard, activity-based costing, cost volume profit analysis and standard costing as other management accounting strategies analysis quantitatively how they will improve the decision making of the organisation. The target population had a group of 20 workers who were categorised into various departments of Capadvise Foods. The researcher used a hundred percent census on questionnaires and interviews so as to gather and launch full data from Capadvise Foods selected divisions and employees.

\section{Discussion of Findings}

\subsection{Challenges Faced in Implementing Management Accounting Techniques in Enhancing Decision Making}

$11 / 20(55 \%)$ respondents strongly agree and 5/20 (15\%) respondents agree that the organization is facing a challenge of insufficient support from the top management to implement management accounting techniques in enhancing decision making. 2/20 (10\%) respondents disagree and 1/20 (5\%) respondents strongly disagree that top management is not supporting implementation of management accounting techniques. $1 / 20(5 \%)$ respondent is uncertain if there is insufficient support from management to implement management accounting techniques. A total of $16 / 20(80 \%)$ respondents ( 11 who strongly agree and 5 who agree) affirmed that there is insufficient support from top management to implement management accounting techniques. This is supported by Tsai (2017) who asserts that the top executives in an organization are usually not concerned to reveal if management accounting techniques have been successfully implemented to enhance good decision-making process of the organization.

$15 \%$ respondents (2 disagree and 1 strongly disagree) rejected that there is insufficient support from top management to implement management accounting techniques. This is supported by Sunarni (2013) saying that top management is not responsible for implementing management accounting techniques, it is the lack of communication between accounting departments and other departments hence management accounting techniques are not coordinated effectively within the organization. The $5 \%$ respondent who is uncertain is likened by Nian and Nair (2017) suggested that qualification and inexperience of the accounting staff hinders the implementation of management accounting techniques to enhance good decision making. The minutes of the 2016 annual general meeting of Capadvise Foods clearly revealed that Capadvise Foods' top management is enthusiastic about the appropriate management accounting practices to improve decision making. Most of the respondents, 16/20 (80\%), (11 strongly agree and 5 agree) agreed that support from top management was found in the manufacturing department and most of the $15 \%$ respondents ( 2 disagree and 1 strongly disagree) denied that it is the lack of support from top management. The findings therefore revealed that coordination between the management and subordinates is very weak which ultimately affect appropriate management accounting practices to be effective in enhancing decision making.

\subsection{Inadequate Information}

$7 / 20(35 \%)$ respondents strongly agree and 9/20 (45\%) respondents agree that the inadequacy of information associated with the implementation of management accounting techniques to enhance decision making is a challenge that the organization is facing. $1 / 20(5 \%)$ respondents is uncertain if the inadequacy of information is a challenge to implement management accounting techniques. $2 / 20(10 \%)$ respondents disagree and $1 / 20(5 \%)$ respondents strongly disagree that indeed the organization is facing problem of inadequate information to implement management accounting techniques. $80 \%$ respondents $(7$ strongly agree and 9 agree) acknowledge that inadequate information is a challenge faced in implementing management accounting techniques within an organization. This position is well supported by Srivastava (2016) stated that inadequate and inappropriate use of management accounting information can detriment the fair view of management decision making.

The 5\% respondents who are uncertain were supported by Butterfield (2016) saying that unqualified accounting staff may lead to inappropriate management accounting techniques ensuing to bad decision making. The total of $15 \%$ respondents (2 disagree and 1 strongly disagree) were greatly supported by Muhsinzoda (2015) and Shanker (2017) saying that absence of management information systems will enhance less information to be provided to decision makers which will enhance less decision making of an organization. In line with the modal responses of $80 \%$ ( 7 who strongly agree and 9 agree) the researcher used the findings 
showing that inadequate information is a challenge that the organization is facing to implement good quality decision making.

\subsection{Rapid Changes in Business Environment}

$6 / 20(30 \%)$ respondents strongly agree and 5/20 (25\%) respondents agree that rapid changes in business environment is the challenge faced in implementing management accounting techniques in enhancing decision making. 6/20 (30\%) respondents are uncertain if rapid changes in business environment has the impact on the implementation of management accounting techniques whilst $2 / 20(10 \%)$ respondents disagree and $1 / 20(5 \%)$ respondents strongly disagree that rapid changes in business environment has an effect in implementing management accounting techniques. This study showed that a total of $55 \%$ respondents $(6$ strongly agree and 5 agree) admitted that rapid changes in business environment has been hindering the implementation of management accounting techniques within an organization. The respondents are supported by Krishnan (2015) and Jovanovic (2015) saying that changes in business environment has imposed new management accounting techniques and impositions of new regulations to be made which has completed the management decision making to be more challenging.

The $30 \%$ respondents who are uncertain concurred with Talhat (2014) by saying that the rapid changes in business environment has caused the emergence of the latest information technology and manufacturing technologies which contributes much in implementing modern and appropriate management accounting techniques in enhancing decision making. Given that 2 disagree and 1 strongly disagrees it means that total $15 \%$ respondents denied that rapid changes in business environment are the challenge that the organization is facing. The trio is supported by Otley (2016) who said that rapid changes in business environment has affected the implementation in a positive manner since new management information is achieved through modern management accounting practices. The minutes of the 2016 annual general meeting of Capadvise Foods emphasized that the changes in business environment has caused conflicts and confusion on the best management accounting practices to be implemented within the organization. In line with the modal responses of a total of $55 \%$ respondents ( 6 strongly agree and 5 agree) basing on the findings this exposed to the researchers that rapid changes in business environment greatly affect the implementation of management accounting techniques in Capadvise Foods.

\subsection{Inexperience of Accounting Staff}

$7 / 20(35 \%)$ respondents strongly agree that the inexperience of accounting staff is a challenge that the organization is facing in order to implement management accounting techniques to enhance decision making. $8 / 20(40 \%)$ respondents agree that inexperience of accounting staff has the impact in implementing management accounting techniques in improving decision making of the company. $2 / 20$ (10\%) respondents are uncertain about whether inexperience of accounting staff has an effect on the implementation of management accounting techniques. 2/20 respondents disagree whilst $1 / 20$ (5\%) respondents strongly disagree that inexperience of accounting staff has no any impact on the implementation of management accounting practices to enhance decision making in an organization. A total of $75 \%$ respondents (7 strongly agree and 8 agree) affirmed that inexperience of accounting staff is the challenge faced by the organization in implementing accounting techniques in enhancing decision making. This position is supported by Nian and Nair (2017) by saying that most of the accounting staff do not appreciate management accounting techniques that enhance decision making of an organization. The $10 \%$ respondents who were uncertain were concurred by Maiga (2013) by saying that many accounting staff are not well versed with modern management accounting techniques because of rapid changes in information technology hence it is not a major problem of the accounting staff of implementing management accounting techniques to achieve good decision. A sum of $15 \%$ respondents ( 2 who disagree and 1 who strongly disagree) were supported by Al-Sayyed (2015) that inexperience of the accounting staff in implementing management accounting techniques is not a major challenge, it is the organization that does not enlarge the knowledge and understanding regarding the formulation and technical know-how to implement appropriate management accounting techniques to enhance decision making. Given a modal response of $75 \%$ respondents ( 8 strongly agree 7 agree) therefore, the researcher made the findings that inexperience of accounting staff is a major challenge that Capadvise Foods is facing in implementing management accounting techniques so as to enhance decision making.

The results shown on Table 2 were used by the researcher to identify if management accounting has an impact in decision making of an organisation. The results on Table revealed that decision making is a dependent variable whilst provision, interpretation and analysis of data, relevant cost analysis, enhancement in communication and creation of budgets and forecasts were used as independent variables to compliment management accounting. (R-square $=0.1737 ; \mathrm{P}<0,01)$. Furthermore, provision, interpretation and analysis of data $(\beta=0.158 ; t=0.50 ; P<0.01)$, creation of budgets and forecasts $(\beta=0.272 ; t=0.94 ; P<0.01)$, relevant cost analysis $(\beta=0.253 ; \mathrm{t}=1.05 ; \mathrm{P}<0.01)$ whilst enhancement in communication $(\beta=0.283 ; \mathrm{t}=1.25 ; \mathrm{P}, 0.01)$. The independent variables jointly explained $55.1 \%$ positive variance in decision making. With $55.1 \%$ positive variance this implied that management accounting has a major impact in decision making. The results above were supported by Freedman (2018) saying that management accounting is vital for strategic decisions, 
complex decisions in respect of make or buy, investigating new market areas and discontinuance of a product line. For such decisions to be made there is need for management accounting information. Therefore, the void hypothesis stated that management accounting has no significant impact in decision making.

Table-2. The impact of management accounting in decision making.

\begin{tabular}{c} 
regress decision making provision interpretation of data creation of budgets and forecasting relevant \\
cost analysis enhancement communication \\
\hline Source
\end{tabular}

4.5. Factors that Affect the Implementation of Management Accounting Techniques in Decision Making

Respondents explained that technological advancement has affected the implementation of management accounting in a positive manner. The respondents said that with advanced technology intra organisational roles will be improved enabling the management to identify management accounting techniques which are best suited with their departments so as to enhance appropriate and accurate decision making. The respondents were supported by Klovienè and Gimzauskiene (2015) giving an illustration that information technology has changed the way in which management formulate the management accounting systems and techniques enabling analysis, interpretation, accurate and assessment of decision making. Furthermore, Klovienè and Gimzauskiene (2015) mentioned that information technology has caused a transformation of budgets and reports which are among the managerial accounting applications and enable the use of advanced management accounting techniques hence enhancing good decision making.

On the intensity of market competition, the respondents explained that growing of international markets and different cultural environment enable the management to reconsider its existing management accounting techniques and strategies in order to meet the competitive market and environment. Krishnan (2015) supported the respondents saying that the implementation of innovative management accounting practices for the management to make sound decision making is due to intensity of market completion. Ahmed (2014) also supported respondents that as time goes on an increase in market competition allows management to advance their management accounting techniques, push the organization to compete with their competitors effectively and allowing organization to formulate improved decisions.

Respondents furthermore, explained that organisational factors do affect the implementation of management accounting practices in enhancing decision making since organisational size explains and justifies the use of management accounting techniques. The respondents were in line with Benelifa (2017) who suggested that the organisational size explains and justifies the use of management accounting techniques, the smaller the company the lower sophisticated management accounting practices are adopted which make it easier for the management to improve the decision-making process. On the factor of organisational strategies respondents alluded that a strategy an organisation adopts in management accounting practices constitutes the logic underlying its interactions with its decision making. Amara and Benelifa (2017) supported the respondents saying that an appropriate management accounting technique should support strategic priorities in order to improve decision making.

\section{Recommendations}

The recommendations suggest that managers and directors should realize the importance of management accounting techniques within Capadvise Foods, looking at the merits it can provide in terms of truthful measures of suitable information and financial performance, trustworthy information for decision making, control and planning of organizations process, Matembele (2014). Management is impressively encouraged to make use of internal reports formulated by management accountants in assisting them to make suitable and accurate decisions that will benefit the organization, Matembele (2014). For decisions to be prepared there is utilization of information from management accounting practices which recline with the decision makers of 
Capadvise Foods. The organization is recommended to establish qualified management accounting staff or management accounting divisions in such departments of the organization. The findings concluded that management accounting is very helpful in provision, interpretation and analysis of data, driving the organization into successful and accurate decision making.

\section{References}

Ahmad, K. (2015). Factors explaining the use of management accounting practices in Malaysian medium-sized firms. Journal of Small Business and Enterprise Development, 22(4), 762-781.Available at: https://doi.org/10.1108/jsbed04-2012-0057.

Ahmed, K. (2014). Factors explaining the use of management accounting practices in Malaysia medium sized firms. International Journal of Business and Management, 22(4), 762-781.

Ahmed, K. (2015). Factors explaining the use of management accounting practices in Malaysia medium sized firms. International Journal of Business and Management, 12(3), 684-760.

Al-Sayyed, S. M. (2015). The impact of the use modern management accounting techniques to streamline decision making in the Jordanian industrial companies. Journal of Business and Management, 7(10), 50-54.

Amara, T., \& Benelifa, S. (2017). The impact of external and internal factors on the management accounting practices. International Journal of Finance and Accounting, 6(2), 46-58.

Amiri, S. (2014). Information technology and its role in accounting practice. International Journal of Economy, Management and Social Sciences, 3(1), 28-32.

Anderson, T., \& Decker, S. (2018). Introduction to management accounting. Virginia: University of Virginia.

Anertey, F., \& Mbuwani, T. (2014). The main cost management techniques. Nigeria: Robert Gordon University.

Ankrah, E., Mensah, C. C. Y., \& Ofori-Atta, K. (2015). The relevance of accounting information in the management of small scale business in the Yilo Krobo District in Ghana. European Journal of Business and Management, 7(8), 181189.

Anna, M. (2017). Diagonistic assessment of forest management accounting. Journal of Accounting and Finance, 23(2), 36-42.

Annemans, F. (2018). The impact of business analytics on management accounting. Denmark: Aarhus University.

Army, L. (2013). The role of budgeting in management process: Planning and control. Journal of Cross-Cultural Management, 15(1), 16-18.

Augustine, D., \& Haryanto, P. (2013). Impact of accounting information for management decision making. International Journal of Applied Research, 2(5), 171-174.

Aurora, J. W. (2013). Research design: Qualitative, quantitative and mixed method approaches. Washington DC, United States: Sage Publications Inc.

Benelifa. (2017). The impact of external and internal factors on the management accounting practices. International Journal of Finance and Accounting, 6(2), 46-58.

Bhutto, H. (2015). Introduction to management accounting. Virginia: University of Virginia.

Breuer, A. (2013). The role of management accounting in the decision making annals universitastics. Journal of Apulensis Series Oecomica, 12(3), 1-10.

Burns. (2013). Management accounting. New York, United States: McGraw.

Butterfield, E. (2016). Managerial decision making and management accounting information. Helsinki Metropolia: University of Applied Sciences.

Chanbari, Y. (2015). Development \& implementation of a balanced scorecard in an academic hospitalised group. Journal of Hospital Medicine, 6(2), 1-9.

Chang, R. (2013). Surface enhanced Raman scattering: Springer Science \& Business Media.

Chigara, B., Moyo, T., \& Mudzengerere, F. H. (2013). An analysis of cost management strategies employed by building contractors on projects in Zimbabwe. International Journal of Sustainable Construction Engineering and Technology, 4(2), 1-13.

Cima. (2017). Management accounting. New York, United States: McGraw.

Cima. (2018). Management accounting. New York, United States: McGraw.

Darly. (2017). Management accounting. New York, United States: McGraw.

Diana, L. (2013). The role of budgeting in management process: Planning and control. Jounal of Cross-Cultural Management, 15(1), 16-18.

Dierynck, B., \& Labro, E. (2018). Management accounting information properties and operations management. Foundations and Trends $\mathbb{R}$ in Technology, Information and Operations Management, 12(1), 1-114.Available at: https://doi.org/10.1561/0200000051.

Drury. (2013). Development \& implementation of a balanced scorecard in an academic hospitalised group. Journal of Hospital Medicine, 8(3), 1-6

Duff, D., \& Evan, P. (2014). Impact of accounting information for management decision making. International Journal of Applied Research, 2(5), 172-184.

Eldenburg. (2017). The role of management accounting in international entrepreneurship. Germany: University of Siegen.

Emma, T. (2016). When is a balanced a balanced scorecard. International Journal of Productivity and Performance, 60(7), 688708.

Farouk, S., \& McLellan, J. D. (2013). Strategy and management accounting practices alignment and its effect on organisational performance. New York: University of Abu Dhabi.

Francis. (2015). Budgets and budgetary control as management tool for ghana metropolitan assembles. Journal of Finance and Accounting, 3(5), 159-163.

Freedman, J. (2018). Cost volume profit relationship \& break even analysis. Retrieved from: http://www.smallbusiness.com. [Accessed 27/10/18]. 
Freedman, J. (2018). Why management accounting is important for decision making. Retrieved from: http://www.smallbusiness.chron.com. [Accessed 14/10/18].

Garteinstein, D. (2018). Advantages of management accounting. Retrieved from http://www.smallbus.com. [Accessed $14 / 10 / 18]$.

Grant, N. A., \& Yeo, T. (2017). Contigency factors accounting information systems. Malaysia: Universiti Utara.

Ha, R. (2017). Development \& implementation of a balanced scorecard in an academic hospitalised group. Journal of Hospital Medicine, 8(3), 1-6.

Hogan, S. W. (2014). The role of management controls in transforming boundaries and sustaining hybrid organisational forms. Foundations and Trends in Accounting, 8(2), 75-141.

Huthcerson, F. (2018). The advantages of management accounting. United States: University of Mcgrew.

Ismail, N. A., \& Al-Eqab, M. (2013). Contigency factors accounting information systems. Malaysia: Northern University.

Johnston, N. (2018). Cost and management accounting. New Delhi, India: Sultan Chand \& Sons Publishers.

Jovanovic, Z. (2015). Management \& changes in business environment. Journal of Busines and Management, 61(2), 143-151.

Khan, M. N., Rizwan, M., Islam, F., \& Aabdeen, Z. U. (2015). The extent of application of standard costing: A comparison of Chinese and Pakistan manufacturing firms. Journal of Economics and Business Adminstration, 2(1), 1-6.

Kloviene, L. (2013). Oganisation of management accounting information in the context of corporate strategy. Bulgaria: University of National World Economy.

Klovienė, L., \& Gimzauskiene, E. (2015). The effect of information technology on accounting system's conformity with business environment: A case study in banking sector company. Procedia Economics and Finance, 32, 17071712.Available at: https://doi.org/10.1016/s2212-5671(15)01476-8.

Krishnan, R. (2015). Management accountant—what ails thee? Journal of Management Accounting Research, 27(1), 177191.Available at: https://doi.org/10.2308/jmar-10461.

Leite. (2015). Factors explaining the use of management accounting practices in Malaysia medium sized firms. International Journal of Business and Management, 12(10), 177-179.

Lien, L. (2018). The role of management process: Planning and control. Journal of Cross-Cultural Management, 18(1), 15-18.

Lognathan, D., \& Srivastava, P. (2016). Impact of accounting information for management decision making. International Journal of Applied Research, 2(5), 171-174.

Lotich, K. (2015). Budgets and budgetary control as management tool for Ghana metropolitan assembles. Journal of Finance and Accounting, 3(5), 159-163.

Maiga. (2013). Budgets and budgetary control as management tool for Ghana metropolitan assembles. Journal of Finance and Accounting, 3(5), 159-163.

Markovic, M. R. (2015). The role of information management in decision making and business success. Belgrade, Serbia: Singidunum University.

Martin. (2017). The role of management accounting in international entrepreneurship. Germany: University of Siegen.

Matembele, K. (2014). Management accounting tools providing sustainability information for decision making and its influence on financial performance. Retrieved from: uir. unisa. ac. za/handle/10500/18990. [Accessed 23 January $2017]$

Matters, G. (2018). The balanced scorecard. Journal of Innovative Performance Measurement Control System, 9(3), 1-13.

Maziriri, E. (2017). An analysis of cost management strategies employed by building contractors on projects in Zimbabwe. International Journal of Sustainable Construction Engineering \& Engineering, 4(2), 1-13.

McConnache, P. (2017). Research design: Arts-based and community based participatory research approaches. New York: United States.

McGrwa, M. (2013). Mixed method research :Instruments, validity, reliability and reporting. Journal of Scientific Research, 6(3), 254-262.

McLellan. (2013). Budgets and budgetary control as management tool for Ghana metropolitan assembles. Journal of Finance and Accounting, 3(5), 123-143.

Meiryuani, S. (2014). Information technology and its role in accounting practice. International Journal of Economy, Management and Social Sciences, 3(1), 28-32.

Metcalf, C. S. (2018). Strategic management accounting and decision making. Nigeria: University of Lagos.

Michael, A. (2016). Relationship between the management accounting techniques and the decision making in the Portugues hotels. Portugual: Polytechnic Institute of Leiria.

Muhsinzoda, D. (2015). The relevance of accounting information in the management of small-scale business in the Yilo Krobo District in Ghana. European Journal of Business and Management, 7(8), 184-186.

Muthyala, V. K. (2017). Importance of management accounting as decision making tool. Retrieved from http://www.linkedin.com. [Accessed 14/10/18].

Muthyala, R. (2016). Development \& implementation of a balanced scorecard in an academic hospitalised group. Journal of Hospital Medicine, 8(3), 1-6.

Mwali, S. (2015). Development \& implementation of a balanced scorecard in an academic hospitalised group. Journal of Hospital Medicine, 6(2), 1-9.

Neislen, T. (2017). The impact of business analytics on management accounting. Denmark: Aarhus University.

Nian, Y., \& Nair, S. (2017). Factors affecting management accounting practices in Malaysia. International Journal of Business and Management, 12(10), 177-179.

Novak, J. H. (2017). A comparison of open ended and closed question in the prediction of mental health. Quality E Quantity, $47(1), 1397-1411$

Oboh, C. S. (2017). Strategic management accounting and decision making. Nigeria: University of Lagos.

Otley, D. (2016). The contingency theory of management accounting and control: 1980-2014. Management Accounting Research, 31, 45-62.Available at: https://doi.org/10.1016/j.mar.2016.02.001. 
Oyerogba, E. O. (2015). Management accounting practices in the developing economies. The Journal of Accounting and Management, 5(2), 76-85.

Parikh, M. (2013). Mixed method research: Instruments, validity, reliability and reporting. Journal of Scientific Research, 6(3), 254-262.

Pavalots, T. (2015). The main cost management techniques. Nigeria: Robert Gordon University.

Phuong, E. (2017). An analysis of cost management strategies employed by building contractors on projects in Japan. International Journal of Sustainable Construction Engineering $\mathcal{E}^{\circ}$ Engineering, 3(12), 1-20.

Piersiala, L. (2017). Cost accounting for management of health services. Journal of Management Accounting Research, 13(8), $1-15$.

Poll, F. (2014). Impact of accounting information for management decision making. International Journal of Applied Research, $2(5), 171-174$

Ponnusamy, L. (2017). The impact of external and internal factors on the management accounting practices. International Journal of Finance and Accounting, 6(2), 46-58.

Ratnatunga, J. (2015). The impact of new technologies on the management accountant. Journal of Management Accounting Research, 13(1), 1-10.

Ray. (2018). Introduction to management accounting. Virginia: University of Virginia.

Reddy, J. (2016). The impact of new technologies on the management accountant. Journal of Management Accounting Research, 13(1), 1-10.

Reistein, W. (2017). The impact of business analytics on management accounting. Denmark: Aarhus University.

Rongala, A. (2015). What is management accounting and its importance. Retrieved from http://www.invensis.net. [Accessed 14/10/18].

Ruliana. (2015). The impact of cost structure on supply chain cashflow risk. International Journal of Production Research, $55(22), 6624-6637$.

Russell, G. W. (2014). The importance of management accounting for professional accountants in business.

Sanni, F., \& Hashim, T. (2013). The main cost management techniques. Nigeria: Robert Gordon University.

Sethy, T. (2017). The impact of business analytics on management accounting. Denmark: Aarhus University.

Shanker, R. (2017). Development \& implementation of a balanced scorecard in an academic hospitalised group. Journal of Hospital Medicine, 8(3), 1-6.

Sharet. (2015). The role of management accounting in international entrepreneurship. Germany: University of Siegen.

Simon, C. W. (2014). Management accounting practices and the role of management accountant. Review of Integrative Business छEEconomics, 2(2), 617-624.

Singh, Y. A. (2017). Management information. Retrieved from http://www.causehero.com. [Accessed 27/10/18].

Siska, L. (2016). The contingency factors affecting management accounting in Czech companies. Acta Universitatis Agriculturae et Silviculturae Mendelianae Brunensis, 64(4), 1383-1392.Available at: https://doi.org/10.11118/actaun201664041383.

Srivastava, P. (2016). Impact of accounting information for management decision making. International Journal Of Applied Research, 2(5), 171-174.

Sulamain, H. (2016). Cost and management accounting. New Delhi, India: Sultan Chand \& Sons Publishers.

Sunarni, C. W. (2017). Management accounting practices and the role of management accountant. Review of Integrative Business \& Economics, 2(2), 617-624.

Sunarni., C. W. (2013). Management accounting practices and the role of management accountant: Evidence from manufacturing companies throughout Yogyakarta, Indonesia. Review of Integrative Business and Economics Research, 2(2), 616-626.

Talhat, C. (2014). The relevance of accounting information in the management of small-scale business in the Yilo Krobo District in Ghana. European Journal of Business and Management, 7(8), 184-186.

Tan, M. (2013). Balanced scorecard a strategy management system of the higher education institution. International Journal of Education Education, 29(2), 167-176.

Tiwari, S. (2015). Standard costing practices, dartmouth board of trustees. United States: University of Massachusetts.

Tsai, C.-Y. (2017). The impact of cost structure on supply chain cash flow risk. International Journal of Production Research, 55(22), 6624-6637.Available at: https://doi.org/10.1080/00207543.2017.1330568.

Vitez, O. (2018). The role of accounting in business. Retrieved from www.smallbus.com. [Accessed 14/10/18].

Wall, C. (2014). Strategic management account in close inter-organisational relationships. Journal of Accounting and Business Research, 45(1), 27-54.

William. (2013). Relationship between the management accounting techniques and the decision making in the Portugues Hotels. Portugual: Polytechnic Institute of Leiria.

Woodruff, J. (2018). Why is financial management so important in business. Retrieved from http://www.smallbus.com. [Accessed 14/10/18].

Yang, Y., Lu, Q. S., Tang, G., \& Pei, J. (2015). The impact of market competition on search advertising. Journal of Interactive Marketing, 30, 46-55.Available at: https://doi.org/10.1016/j.intmar.2015.01.002. 